\title{
Research Aвтісік: Effect of inorganic nutrients and combine effect of inorganic and organic sources of nutrients on vegetative and reproductive growth of guava (Psidium guajava L.) cv. G-27
}

\author{
—. SURAGE, R. LEKHI, MD. JAWED, N. VASURE AND R. JATAV
}

Article Chronicle:

Received :

15.07.2017;

Accepted :

30.07.2017

KeY Words:

Guava, Organic, Inorganic and integrated nutrient management

Author for correspondence :

\section{H. SURAGE}

Department of

Horticulture (Fruit

Science), University

Orchard Farm, College

of Agriculture, GWALIOR (M.P.) INDIA

Email : hemantsurage@ gmail.com

See end of the article for authors' affiliations
SUMMARY : An experiment entitled "Studies on effect of inorganic nutrients and combine effect of inorganic and organic sources of nutrients on growth of guava (Psidium guajava L.) cv. G-27. Gwalior 27 was carried out during 2014-15 at University orchard farm, Department of Horticulture (Fruit Science), College of Agriculture, Gwalior (M.P.). The experiment was conducted in Randomized Block Design with three replications using cv. G-27 with thirteen treatments replicated thrice in a well established guava orchard. Application of nutrients irrespective of their sources and doses, markedly enhanced quality of guava fruits over untreated control. There were four levels of Nitrogen i.e., $600 \mathrm{~g}, 450 \mathrm{~g}, 300$ $\mathrm{g}$ and $150 \mathrm{~g}$, four levels of Phosphorus i.e., $400 \mathrm{~g}, 300 \mathrm{~g}, 200 \mathrm{~g}, 100 \mathrm{~g}$, four levels of Potash i.e., $600 \mathrm{~g}, 450$ $\mathrm{g}, 300 \mathrm{~g}$ and $150 \mathrm{~g}$, plus $5 \mathrm{~kg}$ vermicompost and $10 \mathrm{~kg}$ FYM was applied per plant while the control plants received no fertilizer, inoculation and manure treatment.The morphological parameters of plant were significantly influenced by the integrated nutrient treatments. Results showed the maximum increase in tertiary shoot length $(7.47 \mathrm{~cm})$ shoot diameter $(4.10 \mathrm{~mm})$, and number of leaves per shoot (6.93) and reproductive parameters like No. of flower per Shoot (74.04), Fruit setting (93.20), Fruit drop (44.06), Fruit retention (70.43 at 90 days with the application of $\mathrm{T}_{5}\left(\mathrm{~N}_{1} \mathrm{P}_{1} \mathrm{~K}_{1} \mathrm{~V}_{1}\right)$ which was superior than control.

How to cite this article : Surage, H., Lekhi, R., Md. Jawed, Vasure, N. and Jatav, R. (2017). Effect of inorganic nutrients and combine effect of inorganic and organic sources of nutrients on vegetative and reproductive growth of guava (Psidium guajava L.) cv. G-27. Agric. Update, 12(TECHSEAR-5) : 1204-1207; DOI: 10.15740/HAS/ AU/12.TECHSEAR(5)2017/1204-1207. 